SHS Web of Conferences 2, 00021 (2012)

DOI: $10.1051 /$ shsconf $/ 20120200021$

(C) Owned by the authors, published by EDP Sciences, 2012

\title{
Rehabilitation centers and their role in medical tourism development in latvia
}

\author{
M. Luka ${ }^{1}$ and A. Muiznieks ${ }^{2}$ \\ 1 School of Business Administration Turiba, Latvia \\ 2 Rïga Stradinšs University, Latvia
}

\begin{abstract}
The theme of the research is the possible development of rehabilitation centres in medical tourism. The paper analyses the financial situation of rehabilitation centres in Latvia, the correlation with economical situation in Latvia as well as the comparison of services and prices in Latvian and European rehabilitation centres. A visitors' survey in order to investigate their satisfaction regarding services was conducted in the rehabilitation centre "Jaunkemeri". The findings of the survey are summarized as guidelines (proposals) for the development of Latvian rehabilitation centres in the context of medical tourism. The main research results are as follows: Latvian rehabilitation centres offer a wide variety of services, the prices of the services are competitive with European ones, and the clients are satisfied with the quality of services and believe that the quality corresponds with the price. However, Latvian rehabilitation centres depend on the economical situation of the country and its financial support, there is a lack of unified standards in Latvia, the Soviet infrastructure dominates and the leisure time activities are limited. The aim of the guidelines is to offer a solution of the problem regarding the possibility to develop rehabilitation centres in order to foster the medical tourism and the ways how to do it.
\end{abstract}

Key words: rehabilitation centres, medical tourism, customer satisfaction

Over the past two years the national economical situation of Latvia has had a negative impact on the health care industry. Less and less state budget finances are allocated for medicine, especially rehabilitation. Hospitals and rehabilitation centres are either struggling for survival or have gone bankruptcy. In the end of 2009 the government funding for health care was diminished by Ls 75.52 million (Slišāne, 2010), eventually leading to reducing the amount and variety of health care services. In 2010 Latvian Tourism Development Agency conducted a survey on the latest tendencies in incoming tourism in Latvia (TAVA, 2010), embracing five evaluation criteria: ecological aspects, social aspects, market supply and demand, and estimation of recourses. Medical tourism gained the highest evaluation (87.6 out of 100).

Summarizing, the current situation in Latvia is as follows: the demand in medical tourism is increasing (Eurostat, 2010), but rehabilitation centres are close to bankruptcy because of reduced government funds. Authors suggest a solution to this problem - developing health tourism, especially medical services and rehabilitation, focused on natural resources and traditions.

\section{The aim of the study}

To evaluate the competitiveness of Latvian rehabilitation centres and possibilities of their development in medical tourism. The study focuses on clients' satisfaction in the quality of rehabilitation services in Latvia. The research questions are as follows:

- Are Latvian rehabilitation centres competitive with European centres?

- Are the clients satisfied with the quality of rehabilitation services in Latvia?

- Is the development of rehabilitation centres in medical tourism possible and how to attain it?

This is an Open Access article distributed under the terms of the Creative Commons Attribution License 2.0, which permits unrestricted use, distribution, and reproduction in any medium, provided the original work is properly cited. 


\section{SHS Web of Conferences}

\section{Materials and methods}

Based on the research of literature and Internet sources (Medical Treatment Law, 1997; Tourism Law, 1998; Witt, 1989; Medical Tourism Association, 2010; Latvian tourism development concept, 1997; Goodrich et al., 1987; Gūtenbrunners et al., 2008; Jagyasi et al., 2008; Smith et al., 2009; Rozenvalde, 2009) the authors have determined the essence of medical tourism. Travelling outside the local environment to receive medical services can be defined only as travelling for medical purposes, and the person - a medical traveller. But activities that include this kind of travelling, medical services and direct or indirect interaction with other tourism resources may be defined as medical tourism. Rehabilitation is a process that allows people with movement disabilities and major or long-term illnesses to maintain optimal physical, intellectual, psychological and social condition. Rehabilitation centres are medical institutions that offer medical treatments and spa services (Smith at al., 2009). SPA resorts and rehabilitation centres have specific medical treatments and technical supply, but SPA is mainly focused on client's wellbeing, relaxation and satisfaction, while services offered in rehabilitation centres are more medically oriented (The resort concept of Jurmala city for 2009-2018, 2009).

The basic trends of medical tourism are the following: improving physical health and functionality; losing weight and improving digestion; physical and spiritual relaxation; plastic surgery; dental care; rehabilitation; export-oriented medical treatments for which patients in developed countries have to wait in long lines (Douglas, 2001; Rēvalds, 2010).

Based on the information of Latvian Tourism Development Agency (Rēvalds, 2010; Muižnieks, 2010), the main factors fostering medical tourism development in Latvia are: a relatively high quality of medical treatments, 2-10 times lower prices than in developed countries, professional personnel, geographic location and political status, nature and resources, unknown society, healthy and temperate climate. One of the main obstructive factors is the lack of unified laws in the European Union, that regulate the health care industry, means of paying and doctors' obligations if receiving medical help in foreign countries. Other factors are Latvian doctors' cautious or unwilling attitude towards medical tourism, small and unnoticed marketing activities to attract tourists, lack of legal regulation.

This study includes such research methods as monographic (to analyze the sources of information), statistical (to analyze financial and statistical data), a survey and observation for empirical study, and inductive method (to generalize). The study consists of 5 stages:

1. During stage 1 the essence of medical tourism was analyzed and the main trends discovered.

2. During stage 2 the coherence between rehabilitation centres and economic situation in Latvia was analyzed. The authors chose 5 reh.centres ("Krimulda", "Jantarnij Bereg", "Jaunkemeri", "Ligatne", "Tervete") and analyzed their financial data, determined their profit and/or loss and net turnover. The authors also analyzed the general income of the industry from both state funded and paid services. In order to determine the linear correlation and precise net turnover's dependence on GDP fluctuations, the authors compared the speed of net growth with the speed of GDP growth.

3. The third stage includes the comparison of average prices between Latvia and Europe, calculated in the period from March to April 2010. The authors studied all Latvian rehabilitation centres, their paid services and prices, and compared them with the services and prices abroad. 9 European centres, that had achieved the EUROPESPA MED quality certificates issued by European Spas Association (ESPA), were chosen for comparison.

4. During stage 4 clients' satisfaction with rehabilitation services in Latvia was surveyed in rehabilitation centre "Jaunkemeri" (2009-2010 data). "Jaunkemeri" was selected because of a wide variety of medical treatments, positive income, location in Jurmala (the only Latvian city that has joined ESPA), and the largest share of the paid service market in Jurmala - 34\% (The resort concept of Jurmala city for 2009-2018, 2009).

5. During stage 5 the authors made a SWOT analysis, based on which conclusions and guidelines on the possible development of rehabilitation centres in medical tourism were elaborated. 
Int. Conf. SOCIETY. HEALTH. WELFARE; Congr. of Rehabilitation Doctors of Latvia

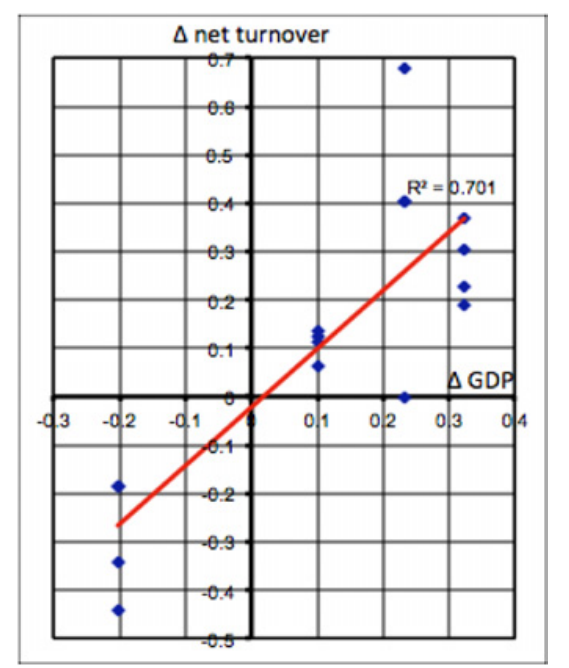

Figure 1. Comparison between rehabilitation centres' net turnover and GDP growth.

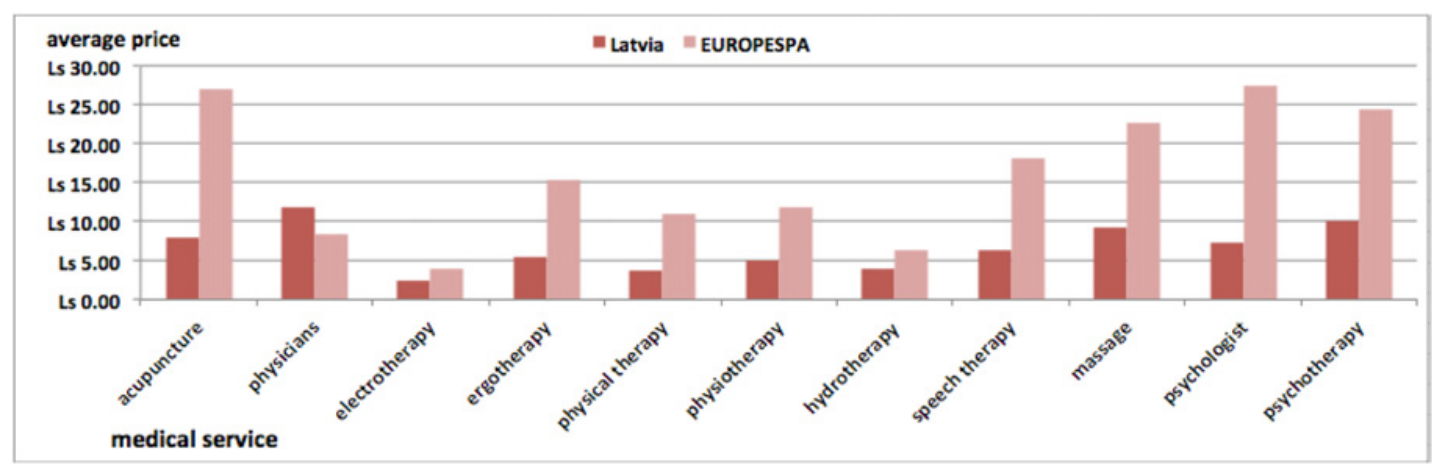

Figure 2. Comparison of average pricing for medical services in Latvia and EUROPESPA.

\section{Results}

The financial analysis shows that 3 out of 5 rehabilitation centres suffered loss at the end of 2009 . The net turnover has increased evenly till year 2008, but since 2009 it has plummeted, which can be partly explained with the reduction of state funds. Then again, the general industry income shows that rehabilitation centres gain higher income from paid services than from the state funding. Analyzing the coherence between GDP and net turnover, the authors conclude that the correlation coefficient is $\mathrm{R}=$ 0.7 (refer to Figure 1), that means that rehabilitation centres depend on GDP fluctuation by $70 \%$. If the GDP is increasing by $10 \%$, so is net turnover. This explains the rehabilitation centres' loss at the end of 2009.

Comparing the average prices of Latvian reh.centres with EUROPESPA, the authors conclude that the prices in Latvia are lower by $41.68 \%$ (refer to Figure 2).

It is important to emphasize the fact that the Latvian prices were compared with the ones of certified centres that can afford to raise their prices, because this certificate lowers the competition between other centres. These nine rehabilitation centres are located in Germany, Czech Republic and Island. 


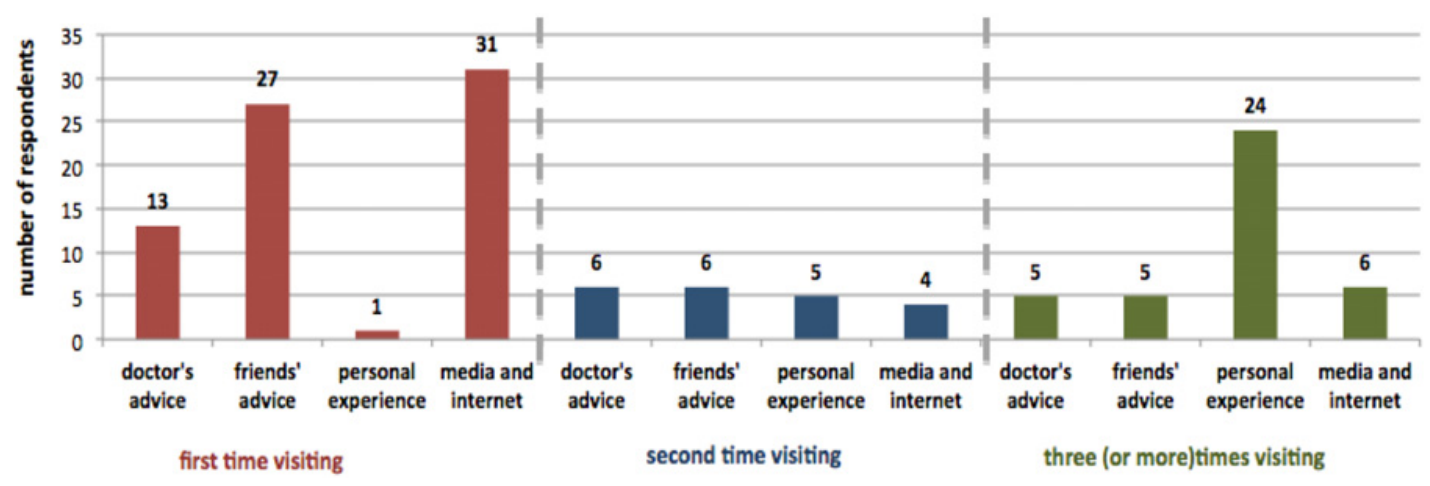

Figure 3. Times of visiting and source of information.

From these three countries Czech Republic is considered to be the main competitor for Latvia, because both services and prices are quite similar to the Latvian ones as well as the main market - Germany is located geographically near. Both Latvian and EUROPESPA rehabilitation centres offer different packages that include medical treatments, SPA services, accommodation and catering. The authors analyzed the proportion between medical treatments and SPA services in these packages. The analysis showed that packages in Latvian rehabilitation centres offer SPA: MED in proportion of 2:3 (from 5 services, 2 are going to be SPA, but 3 - medical), while EUROPESPA packages SPA:MED offer the proportion of 3:2. The average prices for these packages in Latvia are $41.36 \mathrm{Ls}$, while EUROPESPA 122.13 Ls which is 3 times higher. So, in Latvia a client can have 3 times cheaper package with higher concentration on medical treatments.

In the survey of clients' satisfaction on rehabilitation services in Latvia, total of 133 respondents participated, less than $10 \%$ of them were foreigners. From the demographic results the authors determined the basic market for "Jaunkemeri" - women from Riga, age 50-60, that spend on average 8 days in the centre. In this survey the authors clarified times of visiting and source of information. The results showed that $46 \%$ of respondents have been satisfied with the centre, because they have visited the centre repeatedly (refer to Figure 3).

The main reasons for returning are low prices, packages, discounts, and patient's unwillingness to change doctors, services and environment. Clients that visit the centre for the first time found the information from advertisements, Internet and friends, but those, who come repeatedly - from doctor's advice or own experience. That is why it is important to provide a pleasant environment and qualitative services, in order to make the clients return.

Regarding the main reasons of choosing this centre, $72 \%$ stressed the wide choice of medical services (refer to Figure 4). The results show that clients care more about the way of service is done than the quality, in the survey marking peaceful ambiance more important than quality.

Although the quality was not the main reason for choosing "Jaunkemeri", it was because of the quality that $91 \%$ of respondents were satisfied with their visit and $73 \%$ of them think that the price corresponds to the quality of services. Respondents were also asked to evaluate different criteria of the rehabilitation centre "Jaunkemeri" based on their experience during the stay, using the Likert scale (1 very bad, 2 - bad, 3 - medium, 4 - good, 5 - very good) (refer to Figure 5).

As shown in Figure 5, the patients gave a comparatively high evaluation, especially for a variety of medical services (4.35) and attitude of personnel towards patients (4.35), but the lowest evaluation was given to interior (4). According to standard deviation, only 2 factors have dispersion - interior and entertainment (stand.dev. 0.50-1.00). These two factors have the lowest evaluation as well. But the other factors (variety, quality, attitude and catering) are valued higher and standard deviation is insufficient (av.eval. \pm 4.5 ). This means that respondents gave more or less the same evaluation, which was mostly 
Int. Conf. SOCIETY. HEALTH. WELFARE; Congr. of Rehabilitation Doctors of Latvia

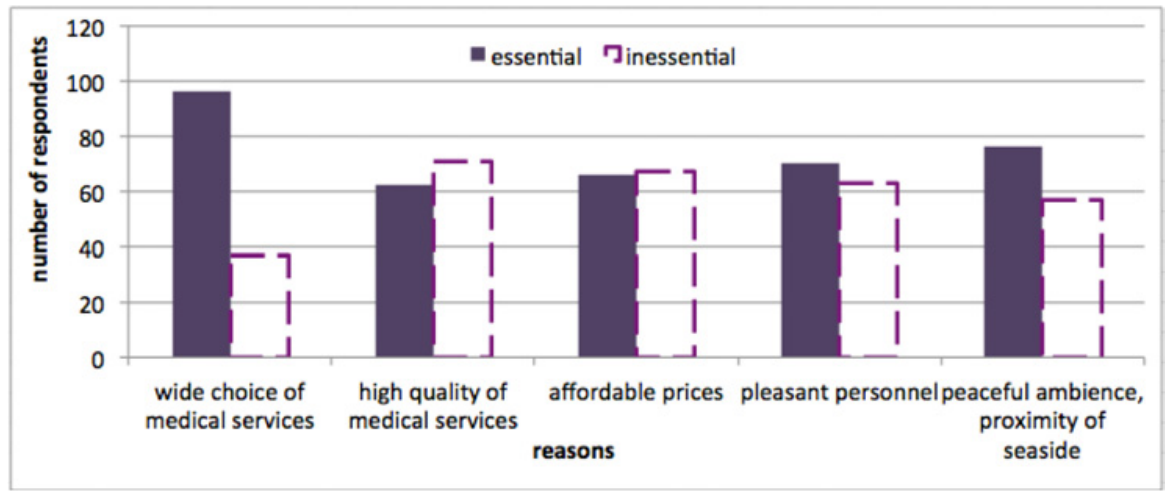

Figure 4. Main reasons for choosing rehabilitation centre "Jaunkemeri".

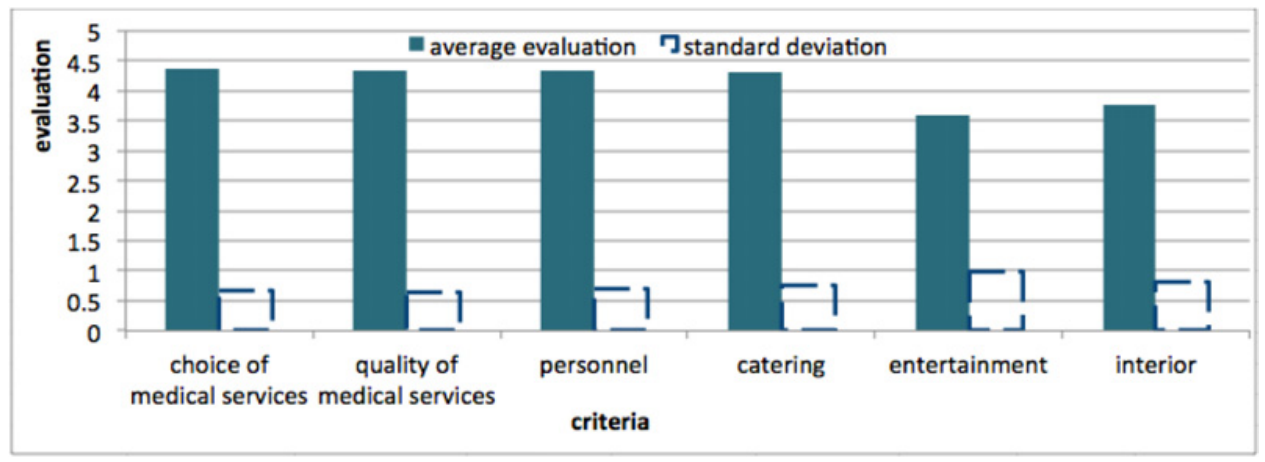

Figure 5. Average evaluation and standard deviation of services and components of "Jaunkemeri".

maximum. This leads to a conclusion that "Jaunkemeri" has successfully estimated their target group and the services are performed according to their expectations. Nevertheless, interior has to be improved (especially in the rooms, according to $45 \%$ requests) as well as entertainment activities that would be more suitable for their target group. The detailed study in medical service evaluation shows that the average evaluation is from 3.5 to 4.5 (refer to Figure 6).

The insignificant standard deviation (0.5-1.0) proves the high satisfaction with the services. Regarding foreign guests, they found information about "Jaunkemeri" on Internet, choosing this centre mainly because of its location (next to the sea), variety and quality of medical services. Foreign guests pointed out reception, bathing, peloid therapy and physiotherapy as the best medical treatments available in the centre (ev.4.67-4.88).

\section{Discussion}

In order to make guidelines, the authors had to estimate the possible development of the potential of rehabilitation in medical tourism by analyzing their strengths, weaknesses, opportunities and threats.

The main strengths are, first of all, the natural curative resources (e.g., mud, climate, mineral water) that are partly renewable and are enough for long-term use. Thanks to these resources Latvia can offer a rich variety of medical and SPA treatments. According to this research, prices in Latvia are competitive with Europe, information about rehabilitation is easily found on Internet in various languages and clients are satisfied with services, quality and price. 


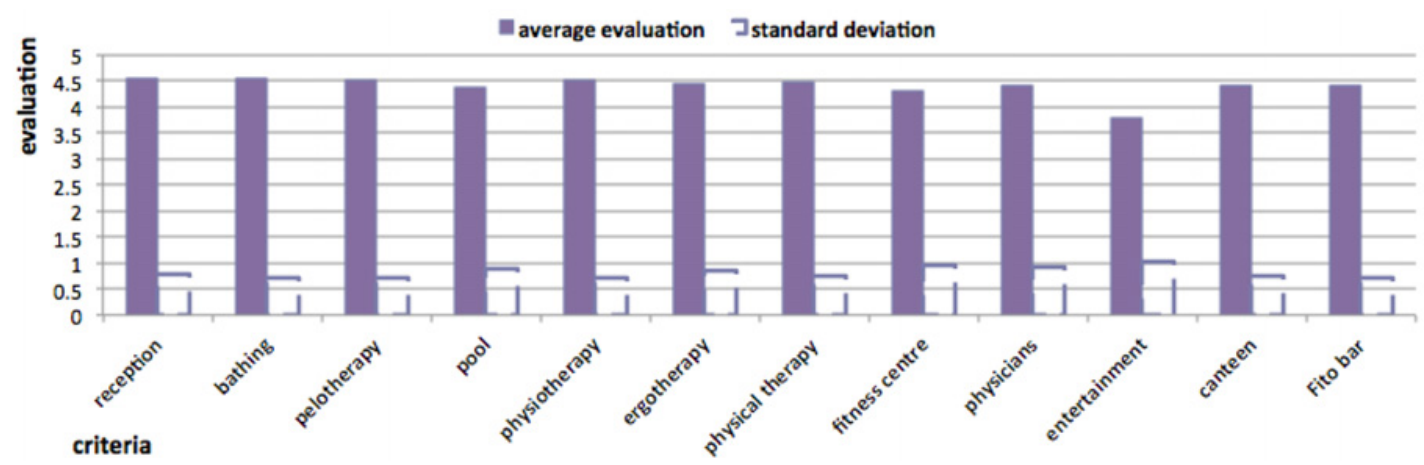

Figure 6. Average evaluation and standard deviation of medical services of "Jaunkemeri".

As for the main weaknesses: dependence on state's economical situation and funding, lack of unified standards for rehabilitation centres in Latvia, lack of recognition in Europe, limited entertainment possibilities (especially in winter), prevalence of Soviet interior.

Analyzing the opportunities of rehabilitation centres in development in medical tourism, the authors found several possibilities. First, merging the national curative resources with high technology would gain better recognition, as well as unified standards and/or certification. Second, marketing activities would attract new clients, since $30 \%$ of patients are searching the information on Internet. Third, investors and business partners could help with finances.

Nevertheless, in case of negative experience (threats), there is a possibility of decreasing demand in particular rehabilitation centres, since $50 \%$ of clients get information from friends and/or selfexperience. Because of recession in Latvia and around the globe the interest in rehabilitation as relaxation (not intensive therapies) may decrease. Another threat is unsustainable development and abusive usage of curative resources.

Based on this study and SWOT analysis the authors elaborated 7 guidelines to develop rehabilitation centres in medical tourism:

1. Evaluation of resources. Estimate the possible development possibilities and specialization for each centre. Study clients' satisfaction; verify the infrastructure, interior, technical and material supply; verify the knowledge of foreign languages for medical and service staff. If necessary, involve private and/or foreign investors in order to receive financing and gain higher independence from state funds.

2. Improving packages for tourists. Improve (for those who have) and/or create new packages for incoming tourists, including medical and SPA therapies, transport, accommodation and catering. Improve and/or create recreational and free time entertainment programs, adjusting to target market's needs. Cultural events, sea side, eco activities and other activities will increase Latvia's competitiveness in Europe.

3. Marketing activities. Focus on e-marketing in order to foster identification of Latvia, its nature, curative resources and rehabilitation centres abroad. Place information on Internet portals which provide information on medical tourism. Cooperate with travel agencies that could sell rehabilitation packages abroad as well as use other information exchange networks. In any marketing activity stress the quality and variety of Latvian rehabilitation therapies as well as their competitive prices. Collaboration with foreign insurance companies would not only foster the incoming medical tourism, but also gain extra funding for modernization, marketing and greater independence from state funding. Marketing activities in local media would widen the local market and make society's opinion positive. 
Int. Conf. SOCIETY. HEALTH. WELFARE; Congr. of Rehabilitation Doctors of Latvia

4. Development of unified quality standards and certification. Professional associations together with non-governmental organizations, businessmen, medical, economical, educational, welfare, environmental and regional development institutions should come up with unified reh.centre quality standards in Latvia or adopt any of the existing ones, e.g. ISO, EUROPESPA MED, JCI and others. Certification of reh.centres would increase Latvia's identification in rehabilitation as well as gain foreign doctors' and visitors' trust in quality.

5. International collaboration. International associations and/or organizations would increase Latvia's recognition in rehabilitation sphere and gain foreign medical tourists' trust.

6. Scientific work. Scientific studies in rehabilitation, publications, conferences, international medical events and so on would also popularize Latvia in rehabilitation sector.

7. Sustainable development. When improving infrastructure, treatment assortments and landscape, focus on securing the natural and curative resources for further use.

As stated in the Eurostat data, the main consumers of healthcare are older people. This section of the European population is growing rapidly, partly as a result of ageing baby-boomers, but also because of continued increases in life expectancy. The increasing number of elderly persons in the coming years will probably drive a demand for more healthcare provision, particularly for long-term care (Eurostat, 2010). This is also reflected in this study, as $66 \%$ of respondents were over the age of 50 .

Although an increasing number of Europeans (and persons from non-member countries) are travelling across borders to receive health treatment, to avoid waiting lists or to seek specialist treatment that may only be available abroad, Latvia is one of the least popular destinations - in which case, the effect of the size of the country should be considered (Eurostat, 2010). This may explain the low number of foreign respondents in the "Jaunkemeri" survey.

The EU works towards ensuring that its citizens who move across borders have access to healthcare anywhere within the EU and healthcare systems and policies are becoming more interconnected (Eurostat, 2010). In Central Europe several new business and revenue models have been developed over the last decade. Hospitals and rehabilitation centres have adopted a new organizational structure an International Department serving the special needs of foreign patients (Buchholz, 2011). Generally speaking, the industry of medical tourism is being surveyed deeply and measures are taken in order to develop it. If Latvia follows the examples of Europe, we may expect increase of foreign patients in reh.centres.

\section{Conclusions}

The financial analysis shows, that rehabilitation centres are dependent on Latvia's economy (correlation coefficient 0.7 ) and state funding for medicine. If GDP is increasing by $10 \%$, so is net turnover for rehabilitation centres. In 2009 rehabilitation centres suffered loss because of diminishing state funding. Turning to medical tourism might solve this problem by gaining larger income, since tourists would buy services. If this happens, centres will gain greater independency from state funding and will be able to improve their infrastructure, services and other necessary things.

Comparing Latvian the average prices of rehabilitation with Europe's example, the authors admit that Latvia has lower prices by $41 \%$. The authors also concluded that the rehabilitation centres in Latvia focus more on medical treatments, while the European ones - on SPA. This means that Latvia has competitive prices and services.

In the clients' satisfaction research the results show that the medical treatments and therapies are performed in good quality, clients are satisfied not only with the service, but also with the way this service is performed. Clients notice every single detail because they are staying there on average 8 days relaxing, both mentally and physically. That is why it is important to fulfil clients' needs and expectations, which can be done through qualified service, entertainment possibilities, interior, environment, attitude and caring. 


\section{SHS Web of Conferences}

The results of SWOT analysis show that Latvia is competitive with Europe because of the wide variety of curative treatments and low prices; clients are satisfied with the quality of the services. The curative resources available in Latvia (e.g. mud, mineral water, climate) are long lasting and in large quantity. Nevertheless, there has to be a research done in sustainable usage for both, medical and preventive purposes. There are no unified quality standards or certificates in Latvia for rehabilitation centres, no recognition in Europe and marketing activities are too minimal to be noticed. All this prevents medical tourism from developing.

Based on the guidelines the authors conclude that rehabilitation development in medical tourism is possible. Medical tourism would give financial support for rehabilitation centres, make them less dependent on state funds and help to increase the profit.

\section{References}

[1] Medical Treatment Law. Adopted on 12.06.1997; approved on 01.10.1997; with amendments to 01.01.2010. http://www.likumi.lv/doc.php?id=44108

[2] Buchholz, M. (2011) European spa tradition. The new face of health tourism in Central Europe. The Slovenia Times, 17 April, 2011.

[3] Douglas, N. (2001) Special Interest Tourism. Australia: John Wiley \& Sons, 475 p. Europe in figures. Eurostat Yearbook 2010. Luxembourg: Publications Office of the European Union, 664 p.

[4] Goodrich, J.N., Goodrich, G.E. (1987) Health-care Tourism - An Exploratory Study. Tourism Management, 8, p. 217-222.

[5] Gūtenbrunners, Kr., Glēzeners, Ž.Ž. (2008) Rehabilitācija, fizikālā medicīna un dabas dziedniecība. [Rehabilitation, physical medicine and nature treatment] Rīga: SIA "Nacionālais apgāds", 100.-116. lpp.

[6] Jagyasi, P. (2008) Defining medical Tourism - Another Approach. Medical Tourism Magazine. http: //www . medicaltourismmag . com/issue-detail . php?item=136\&issue=6

[7] Jūrmalas pilsētas kūrorta koncepcija 2009. - 2018. gadam. [The resort concept of Jurmala city for 2009-2018] (2009) Pieņemta Jūrmalā, 2009. gada novembrī, apstiprināta Jūrmalas pilsētas domes sēdē 2009. gada 17. decembrī. http: //www . jurmala. lv/page/341

[8] Latvijas tūrisma attīstības koncepcija. [Latvian tourism development concept] (1997) Vides aizsardzības un reǵionālās attīstības ministrija, akceptēta Ministru kabinetā 02.12.1997. http://www.em.gov.1v/em

[9] Medical Tourism Association. (2010) http://www.medicaltourismassociation.com/ Muižnieks, A. (2010) Veselības tūrisma tendences Latvijā un Eiropā. [Health tourism trends in Latvia and Europe] http://tava.gov.1v/akt/index.php?akt_id=118

[10] Rēvalds, M. (2010) Veselības tūrisma iespējas Latvijā skaistumkopšanas un veselības aprūpes institūciju skatījumā. [Opportunities of health tourism in Latvia from the point of view of beauty parlours and health care institutions] http://tava.gov.lv/akt/index.php?akt_id=119

[11] Rozenvalde, I. (2009) Tūrisms un veselība. [Tourism and health] Tūrisms, 4 (11), p. 32-33.

[12] Slišāne, L. Izmaiņas medicīniskās rehabilitācijas saņemšanas nosacījumos. [Changes in conditions for receiving medical rehabilitation] Leta, 15 July, 2009. http://www.nozare. lv/nozares/health/item/2009071517320802BA72AF5F88EEF781/

[13] Smith, M., Puczko, L. (2009) Health and Wellness Tourism. Oxford: Butterworth-Heinemann, $400 \mathrm{p}$.

[14] Tourism Law (1998) Adopted on 07.10.1998; approved on 01.01.1999; with amendments to 13.01.2010. http://www. likumi.lv/doc.php?id=50026

[15] Tūrisma veidu un tiem pakārtoto tūrisma produktu grupu izvērtējums [Evaluation of tourism types and the groups of products connected with it] (2010) TAVA pētījums.

[16] Witt, C., Witt, S.F. (1989) Does health tourism exist in the UK. Tourism Review, 44, p. 26-30. DB Emerald; DOI: 10.1108/eb058026 p. 5. 